\title{
Metabolites of Tobacco- and E-Cigarette-related Nitrosamines Can Drive $\mathrm{Cu}^{2+}$-mediated DNA Oxidation
}

Rumasha N. T. Kankanamage, ${ }^{\mathrm{a}, 1}$ Abhisek Brata Ghosh, ${ }^{\mathrm{a}, 1}$ Di Jiang, ${ }^{\mathrm{a}}$ Karmel Gkika, ${ }^{\mathrm{b}}$ Tia Keyes, ${ }^{\mathrm{b}}$ Laura A. Achola, ${ }^{a}$ Steven Suib, ${ }^{\text {a,c James F. Rusling }}$ a,c,d,e

a Department of Chemistry, University of Connecticut, Storrs, CT 06269, USA.

${ }^{\mathrm{b}}$ School of Chemical Sciences, Dublin City University, Dublin 9, Ireland

${ }^{\mathrm{c}}$ Institute of Material Science, Storrs, CT 06269, USA.

d Department of Surgery and Neag Cancer Center, UConn Health, Farmington, CT 06032.

e School of Chemistry, National University of Ireland at Galway, Ireland.

\section{SUPPORTING INFORMATION}

\section{Table of Contents}

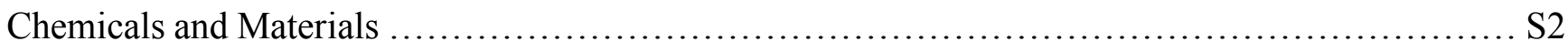

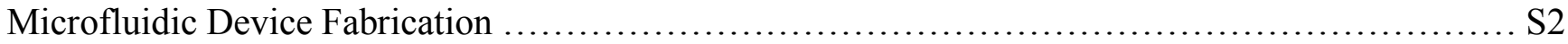

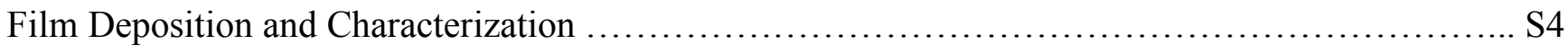

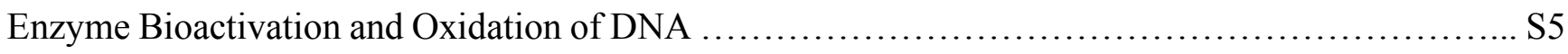

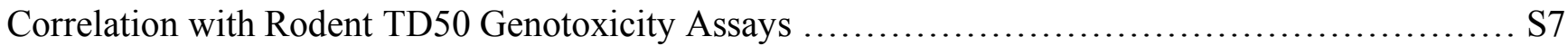

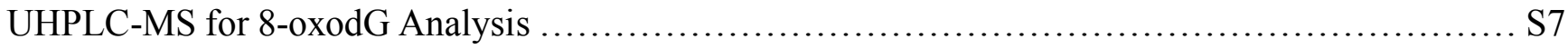

Elucidation of Metabolite Formation and DNA Oxidation by UHPLC-MS/MS .................. S9

Prediction of Fragmentation Patterns of Metabolites by ACD/MS-Fragmenter Software ............ S10

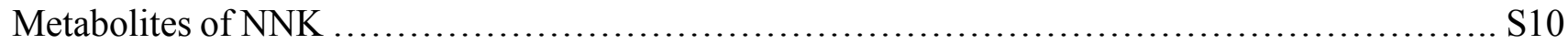

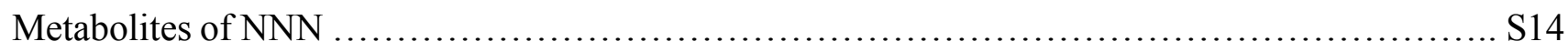

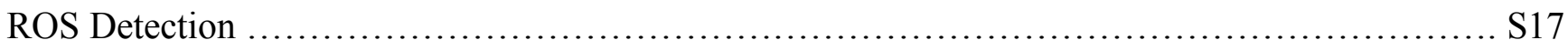

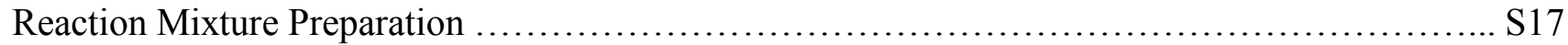

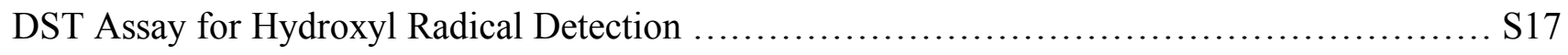

NBT Assay for Superoxide Radical Detection ......................................... S17

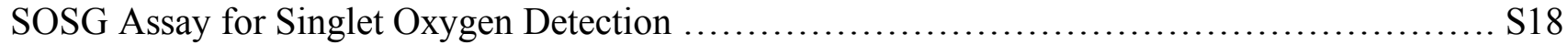

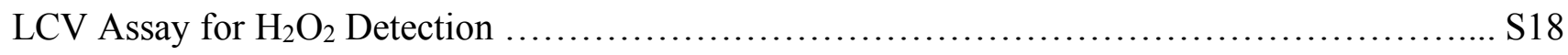

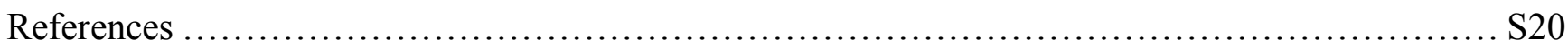




\section{Experimental Details}

\section{Chemicals and Materials}

4-(Methylnitrosamino)-1-(3-pyridyl)-1-butanone (NNK, MW 207.23) and N'-nitroso nornicotine (NNN, MW 177.20) were from Toronto Research Chemicals. $\beta$-nicotinamide adenine dinucleotide phosphate sodium salt hydrate $\left(\mathrm{NADP}^{+}\right)$, glucose-6-phosphate dehydrogenase (G6PDH), glucose-6phosphate (G6P), Poly(diallyldimethylammonium chloride) (PDDA, avg. MW 100,00-200,00), salmon testes (ST) ds-DNA (2000 bp avg.), $\mathrm{CuCl}_{2}, \mathrm{FeCl}_{2}, \mathrm{MgCl}_{2}$ and other chemicals were from Sigma-Aldrich. Mixed gender human lung microsomes-nonsmoker (HLuM, $10 \mathrm{mg} / \mathrm{mL}$ in $250 \mathrm{mM}$ sucrose), pooled male human liver microsomes (HLM, $20 \mathrm{mg} / \mathrm{mL}$ in $250 \mathrm{mM}$ sucrose) and mixed gender human intestine microsomes (HIM, $20 \mathrm{mg} / \mathrm{mL}$ in $250 \mathrm{mM}$ sucrose) were from Sekisui XenoTech. Supersome, cytochrome P450 2B6 (Cyt P450 2B6, 0.5 nmol P450 in $0.5 \mathrm{~mL}$ ) was from Corning Life Sciences. PG sheets $(70 \mu \mathrm{m}$ thick) from Panasonic PGS-P13689-ND.

All reagents and chemicals were analytical grade. Osmium metallopolymer $\left[\mathrm{Os}(\text { tpy-benz-COOH})_{2}\right]^{2+}$ was synthesized and characterized as described in literature. ${ }^{1,2}$ Pyrolytic graphite sheet (Panasonic) was purchased from Graphite store. All solutions were prepared using $18 \mathrm{M} \Omega \cdot \mathrm{cm}$ water by passing house distilled water through a Hydro Service and Supplies purification system (Durham, NC, USA). The ACD/Lab MS-Fragmenter software was from Advanced Chemistry Development, Inc. (ACD/Labs).

Microfluidic Device Fabrication. ${ }^{3,4}$ The device consists of individual chambers to hold wash buffer and sample and a detection channel. It was 3D printed with a Formlabs Form 3 stereolithographic printer using clear polyacrylate resin. A pyrolytic graphite sheet (PGS) chip containing a row of eight printed microwells was sealed with adhesive (Aleene's ${ }^{\circledR}$ Instant Tacky ${ }^{\mathrm{TM}}$ ) to the open lower part of the detection channel (Figure S2A). Microwells were printed in a computer-generated pattern using toner ink in a laser printer on a glossy paper and then heat transferred (at $143{ }^{\circ} \mathrm{C}$ for $90 \mathrm{sec}$ ) to the PG, creating $1 \mathrm{~mm}$ diameter wells $10-15 \mathrm{~nm}$ deep (Figure S2B). Each microwell can hold a $1.0 \pm 0.1 \mu \mathrm{L}$ aqueous droplet, and the toner walls create a hydrophobic barrier to prevent cross-contamination with neighboring wells. Fabrication of the ECL sensor array is shown in Figure $\mathrm{S} 1 . \mathrm{Ag} / \mathrm{AgCl}$ reference and Pt counter electrode wires were placed through the detection channel holes into suitable grooves and holes so that they both run the entire length of the microwells in a symmetric pattern (Figure S2A). 


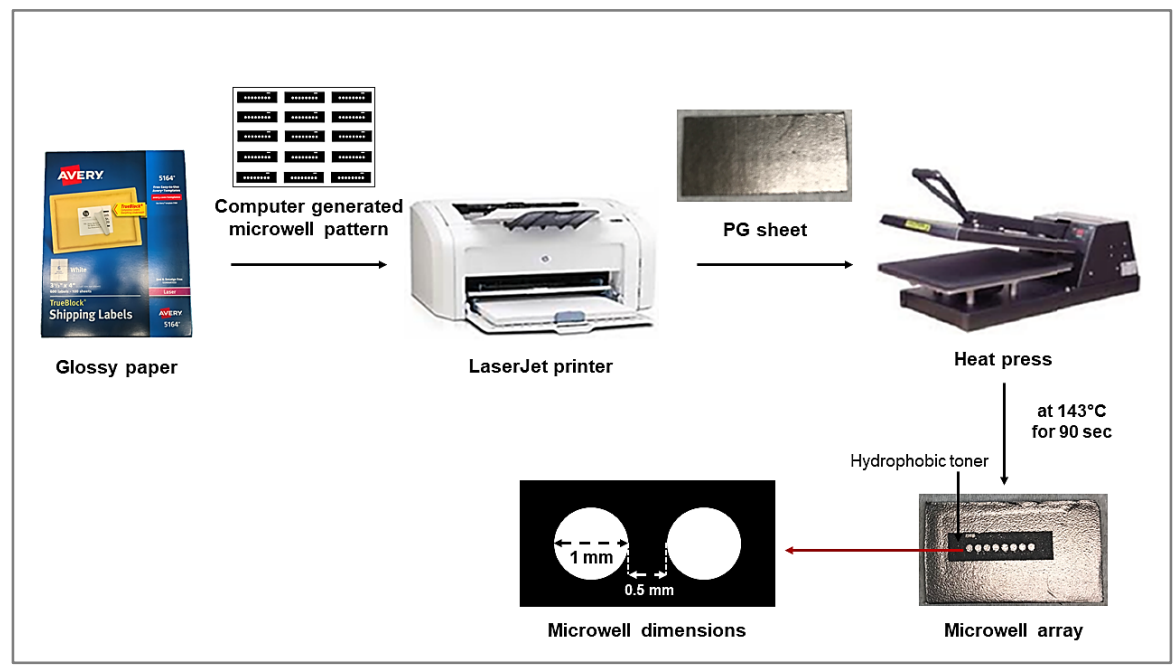

Figure S1. Fabrication of microwells on Pyrolytic Graphite sheet (PGS). Hydrophobic toner pattern to was designed with Inkscape, then printed onto high gloss paper using an HP LaserJet printer. The toner pattern was then transferred onto the PGS heat press at $143^{\circ} \mathrm{C}\left(290^{\circ} \mathrm{F}\right)$ for $90 \mathrm{~s}$.

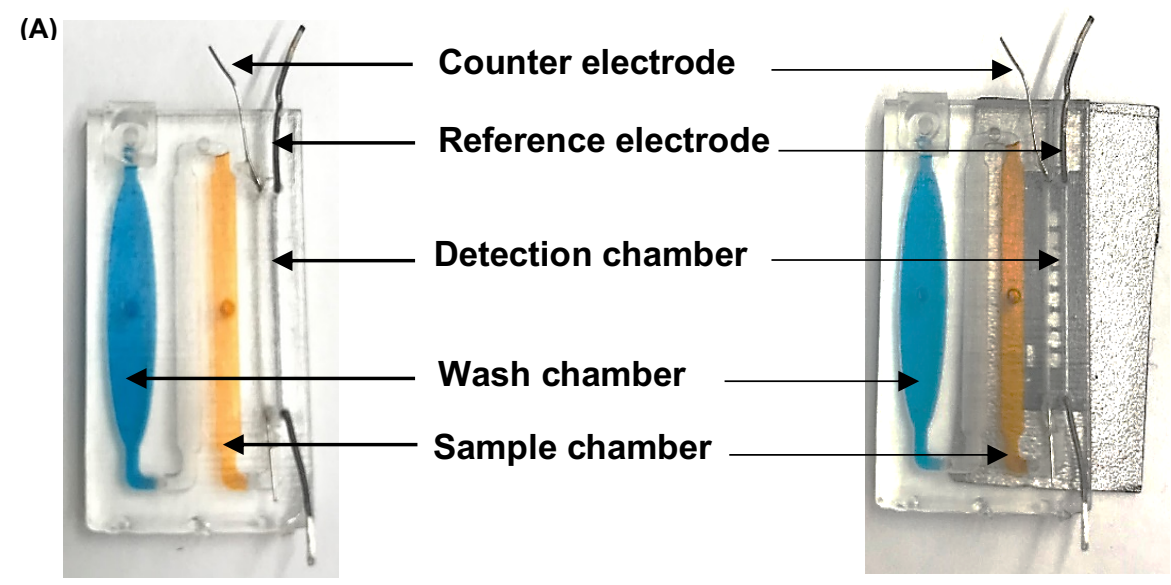

3-D Printed Microfluidic Array

(B)

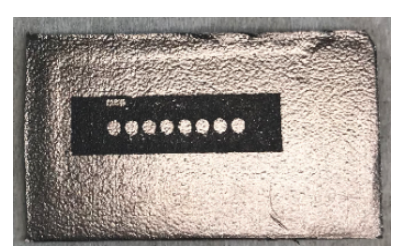

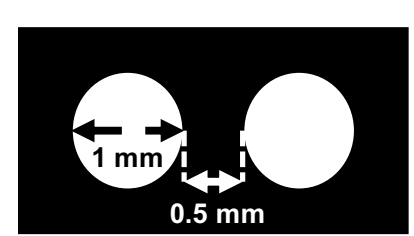

Microwell dimensions

Patterned Sensor

Figure S2. DNA oxidation array: (A) 3-D printed microfluidic device without (left) and with (right) microwell sensors showing Pt counter, and $\mathrm{Ag} / \mathrm{AgCl}$ reference electrode wires and dye-filled wash and sample chambers. Microwell-patterned sensor array (left) with hydrophobic toner boundaries. Each microwell holds about $1 \mu \mathrm{L}$ of solution and each microwell in the working array contains $\mathrm{LbL}$ films of PDDA, DNA and metabolic enzymes. A microwell is $1 \mathrm{~mm}$ in diameter and the distance between two adjacent microwells is $0.5 \mathrm{~mm}$ (right).

Film Deposition and Characterization. Alternate charge layer-by-layer (LbL) assembly was used in the order (PDDA/DNA) 3 /cyt P450 source/PDDA/DNA to grow films. (Scheme S1). The concentrations of solutions and incubation times were optimized. Compositions were: PDDA, $2 \mathrm{mg} \mathrm{mL}^{-1}$ in $0.05 \mathrm{M}$ $\mathrm{NaCl}$, pH 7.2 was incubated for 20 min after deposition; salmon testes DNA, $2 \mathrm{mg} \mathrm{mL}^{-1}$ in $10 \mathrm{mM}$ TRIS + 0.5 M NaCl, pH 7.4; HLuM, $10 \mathrm{mg} \mathrm{mL}^{-1}$ in $250 \mathrm{M}$ sucrose; HLM and HIM, $20 \mathrm{mg} \mathrm{mL}^{-1}$ in 250 
$\mathrm{mM}$ sucrose; cyt P450 supersome 2B6, $0.5 \mathrm{nmol}$ in $0.5 \mathrm{~mL}(\mathrm{pH} 7.4)$. The incubation time for DNA and respective enzymes is $30 \mathrm{~min}$ each. One layer at a time was deposited in $1 \mu \mathrm{L}$ droplets of PDDA, DNA, and enzyme solutions in microwells sequentially followed by washing with $18 \mathrm{M} \Omega \mathrm{cm}$ water between two consecutive depositions. Enzymes sources were human organ specific microsomes and some supersomes including human lung microsomes (HLuM), human liver microsome (HLM), human intestine microsome (HIM) and supersome cyt P450 2B6. Films with the various enzyme sources were grown in different microwells in sensor chips. ECL generating dye $\left[\mathrm{Os}(\text { tpy-benz-COOH })_{2}\right]^{2+}$ was delivered in solution phase prior to the detection of ECL. Mass densities and thickness of the film layers was measured by a quartz crystal microbalance (QCM, USI Japan). Gold resonators were functionalized with a monolayer of 3-mercaptopropionic acid, by incubating in $0.5 \mathrm{mM} \mathrm{3-mercaptoprpionic} \mathrm{acid} \mathrm{in}$ ethanol overnight. The stability of each layer was optimized and frequency change $(\Delta \mathrm{F})$ was measured after washing with $18 \mathrm{M} \Omega \cdot \mathrm{cm}$ water and drying in a stream of nitrogen (Figure S3, Table S1).

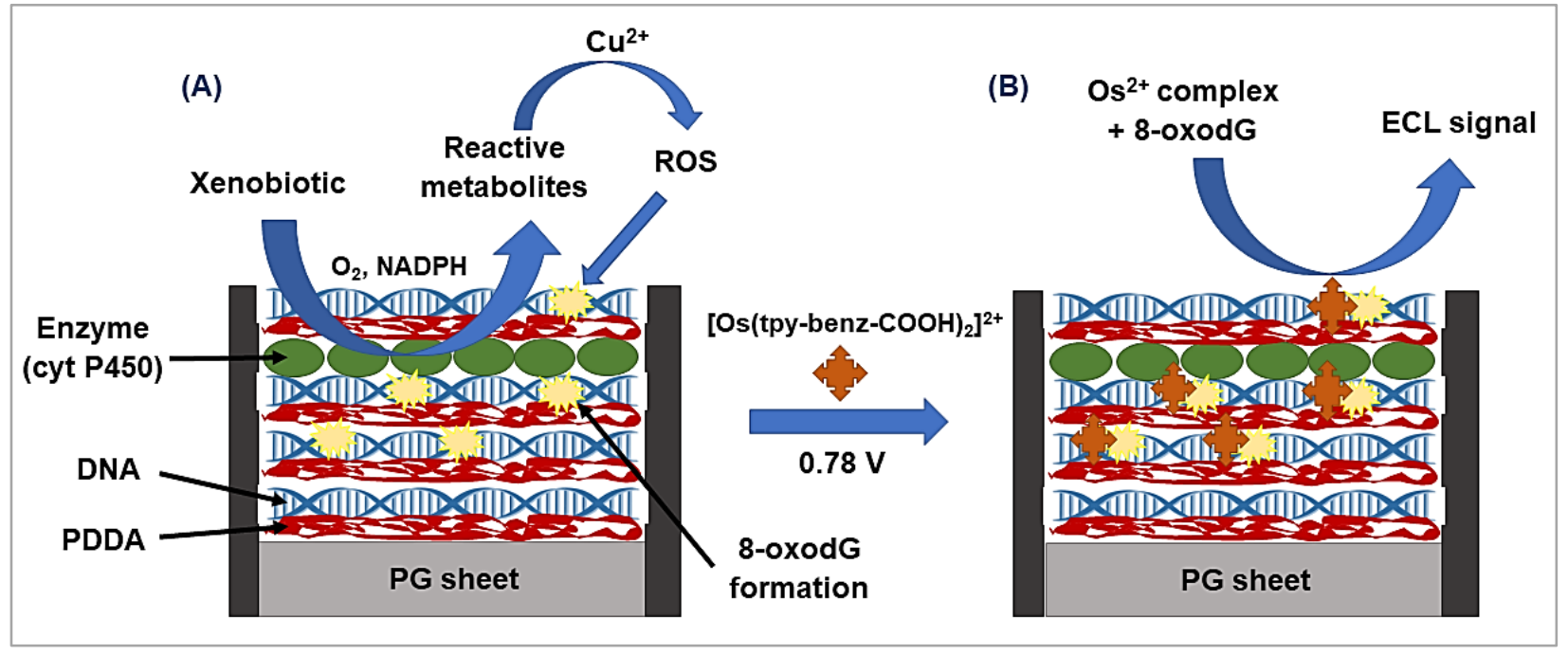

Scheme S1. Representation of single microwell in sensor array with (PDDA/DNA) 3 /cyt P450 enzyme source/PDDA/DNA film. (A) bioactivation of cyt P450 enzyme and metabolism of substrate xenobiotic in the presence of $\mathrm{O}_{2}, \mathrm{NADPH}$ and $\mathrm{Cu}^{2+}$. (B) Generation of ECL by the reaction between co-reactant 8oxodG and dye $\left[\mathrm{Os}(\text { tpy-benz-COOH })_{2}\right]^{2+}$ upon applying a $0.78 \mathrm{~V}$ vs $\mathrm{Ag} / \mathrm{AgCl}$. 

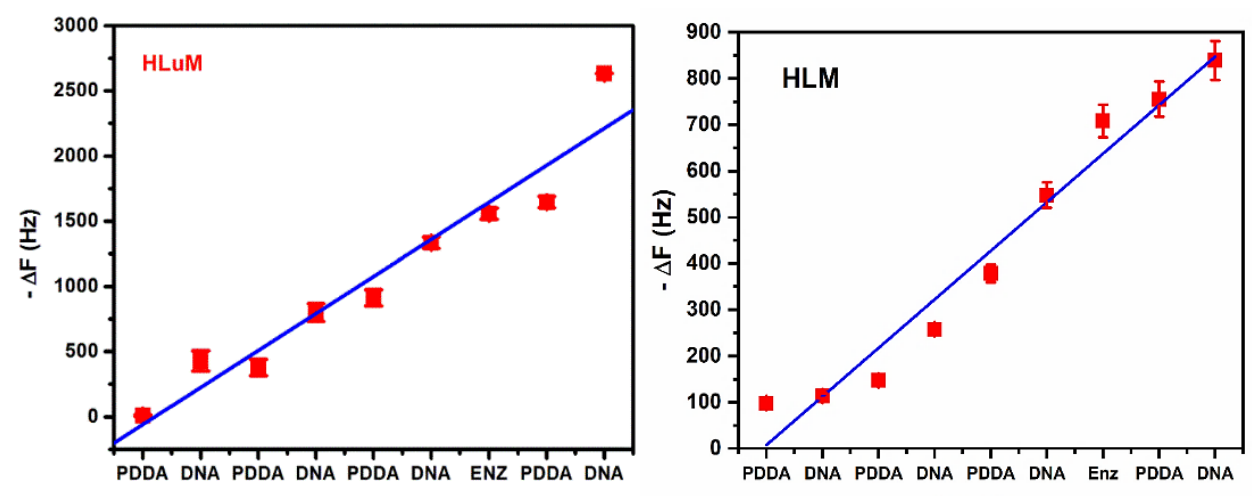

Figure S3. Quartz crystal microbalance frequency shifts for alternate adsorption on gold quartz resonators for (PDDA/DNA) 3 /HLuM, HLM, HIM,
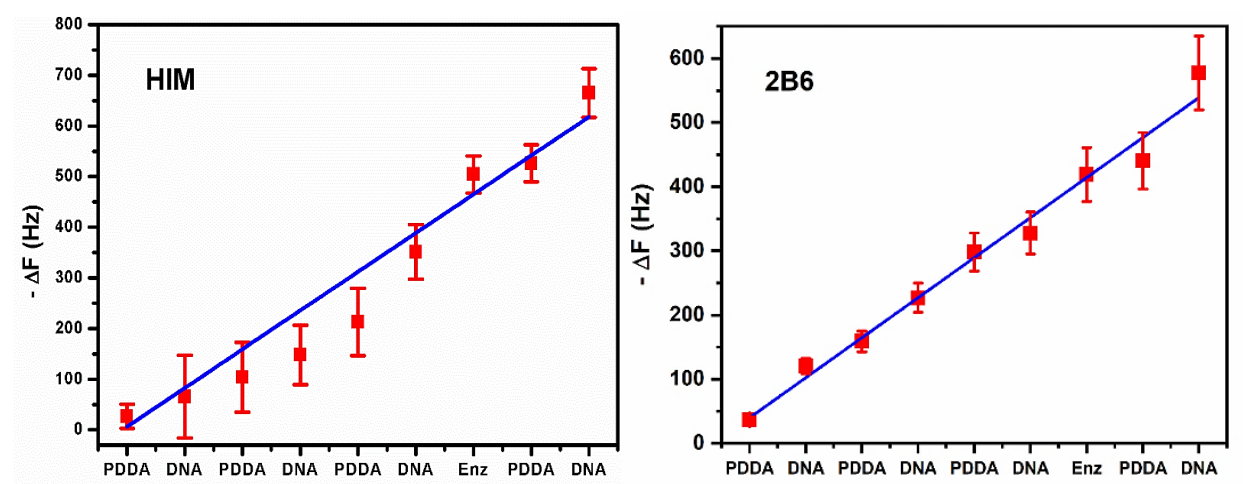

2B6/PDDA/DNA.

Table S1. Average composition and thickness of PDDA/DNA/Enzyme films from QCM.

\begin{tabular}{|c|c|c|c|c|}
\hline & HLuM & HLM & HIM & 2B6 \\
\hline Nominal thickness $(\mathrm{nm})$ & 29 & 23 & 21 & 18 \\
\hline Mass Density PDDA $\left(\mu \mathrm{g} / \mathrm{cm}^{2}\right)$ & $1.29 \pm 0.11$ & $1.88 \pm 1.63$ & $1.19 \pm 0.20$ & $1.27 \pm 0.95$ \\
\hline Mass Density DNA $\left(\mu \mathrm{g} / \mathrm{cm}^{2}\right)$ & $2.84 \pm 0.02$ & $3.87 \pm 0.91$ & $2.75 \pm 0.56$ & $2.29 \pm 1.02$ \\
\hline Mass Density cyt P450 $\left(\mu \mathrm{g} / \mathrm{cm}^{2}\right)$ & $2.98 \pm 0.57$ & $2.40 \pm 1.75$ & $2.72 \pm 1.46$ & $2.87 \pm 1.06$ \\
\hline
\end{tabular}

Enzyme Bioactivation and Oxidation of DNA. The nitrosamines were 4 [methyl(nitroso)amino]-1- (3pyridinyl)-1-butanone (NNK) and $N^{\prime}$-nornicotine (NNN). To oxidize DNA, ROS were generated inside the microfluidic device by delivering solutions of $2 \mathrm{mM} \mathrm{NNK}$ and $\mathrm{NNN}$ in $50 \mathrm{mM}$ phosphate buffer $\mathrm{pH}$ 7.4 including an NADPH regenerating system $\left(1 \mathrm{U} / \mathrm{mL}\right.$ G6PDH enzyme, $2.5 \mathrm{mM} \mathrm{G6P,} 2 \mathrm{mM} \mathrm{NADP}{ }^{+}$, $1 \mathrm{mM} \mathrm{Mg}^{2+}$ ) and $5 \mathrm{mM} \mathrm{CuCl}_{2}$ at $250 \mu \mathrm{L} \mathrm{min}^{-1}$ to the detection chamber of array with microwells containing films of (PDDA/DNA) 3 /cyt P450 enzyme source/ PDDA/DNA (Scheme S1A).

The concentration of $\mathrm{NADP}^{+}$was optimized first to be used in the NADPH regeneration system for enzyme bioactivation. Four different concentration of $\operatorname{NADP}^{+}(0.5 \mathrm{mM}, 1 \mathrm{mM}, 2 \mathrm{mM}$ and $5 \mathrm{mM})$ were tested with previously reported concentrations of other components of NADPH regeneration system (1 
U/mL G6PDH enzyme, $\left.2.5 \mathrm{mM} \mathrm{G6P,} 1 \mathrm{mM} \mathrm{Mg}^{2+}, 1 \mathrm{mM} \mathrm{Cu}^{2+}\right)^{3}$ and $2 \mathrm{mM}$ was chosen as the optimized concertation and utilized in ECL, ROS detection and UHPLC-MS/MS experiments (Error! Reference source not found.). Concentration of $\mathrm{Cu}^{2+}$ was also optimized as described above with six different concentrations $(0.5 \mathrm{mM}, 1 \mathrm{mM}, 2 \mathrm{mM}, 5 \mathrm{mM}, 7.5 \mathrm{mM}$ and $10 \mathrm{mM})$ and $5 \mathrm{mM} \mathrm{Cu}^{2+}$ was chosen as the optimized concentration for most experiments, because after $5 \mathrm{mM}$ of $\mathrm{Cu}^{2+}$, ECL linearly increased with increasing concentration of $\mathrm{Cu}^{2+}$ (Figure S5).

The bioactivation of the cyt $\mathrm{P} 450$ in microsomal and supersomal films was initiated during the incubation with the oxygenated test solution containing the NADPH regenerating system to form reactive metabolites of NNK and NNN. ${ }^{5}$ The channels were washed for 2 min with $50 \mathrm{mM}$ phosphate buffer and then $2 \mathrm{mM}\left[\mathrm{Os}(\text { tpy-benz-COOH})_{2}\right]^{2+}$ was introduced inside. The Os solution were allowed to stay for 2 min while flow was stopped to react completely with the oxidized DNA. Amperometry was done at 0.78 $\mathrm{V}$ vs $\mathrm{Ag} / \mathrm{AgCl}(0.14 \mathrm{M} \mathrm{KCl})$ and ECL light was captured using a charged coupled device (CCD) camera (G:BOX, Syngene), as depicted in Scheme S1B. A possible mechanism for ECL generation with $\left[\mathrm{Os}(\text { tpy-benz-COOH })_{2}\right]^{2+}$ complex is shown in Scheme S2.

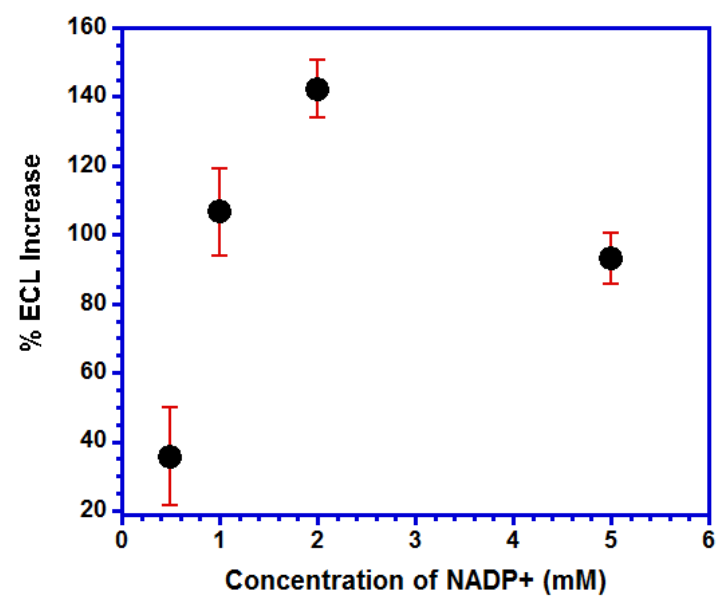

Figure S4. ECL array results for optimization of $\mathrm{NADP}^{+}$ concentration. Among four different concentrations $(0.5$ $\mathrm{mM}, 1 \mathrm{mM}, 2 \mathrm{mM}$ and $5 \mathrm{mM}$ ) used, the highest \% ECL increase was given with $2 \mathrm{mM} \mathrm{NADP}{ }^{+}$concentration.

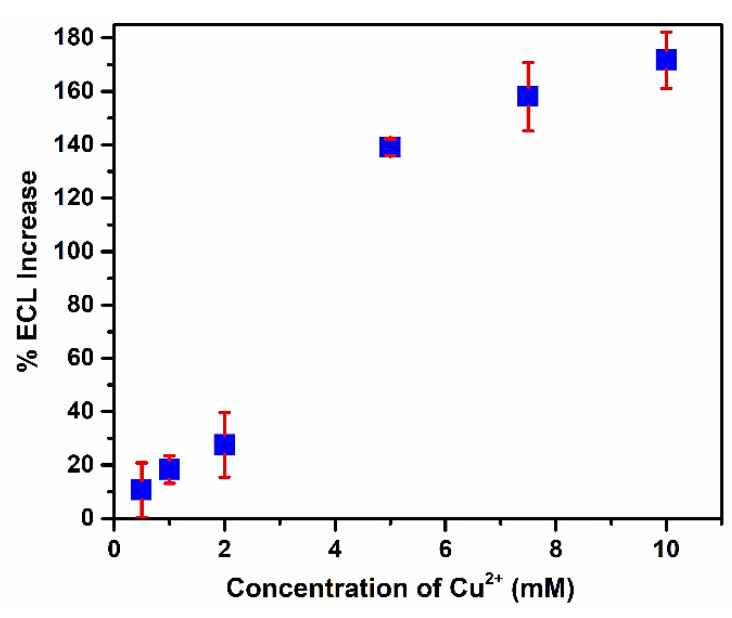

Figure S5. ECL array results for optimization of $\mathrm{Cu}^{2+}$ concentration. Among six different concentrations $(0.5$ $\mathrm{mM}, 1 \mathrm{mM}, 2 \mathrm{mM}, 5 \mathrm{mM}, 7.5 \mathrm{mM}, 10 \mathrm{mM})$ used, $5 \mathrm{mM}$ $\mathrm{Cu}^{2+}$ was chosen as the optimized concentration. 


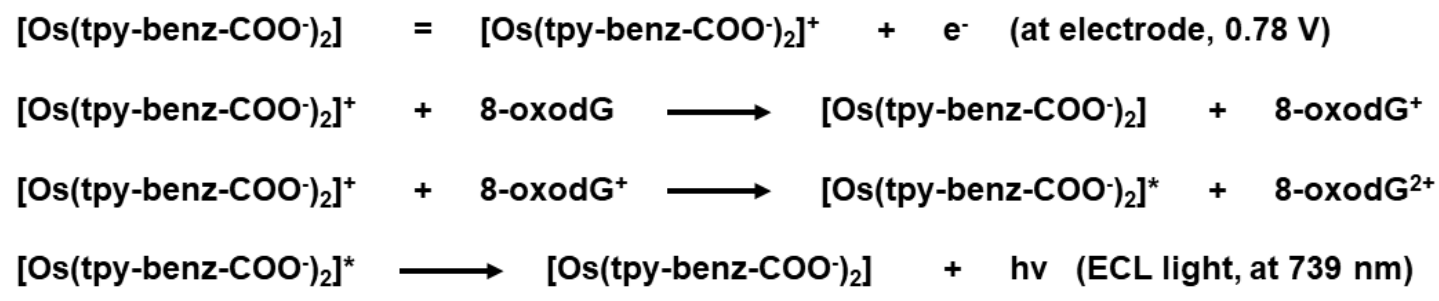

Scheme S2. Pathway for $\left[\mathrm{Os}(\mathrm{tpy}-\mathrm{benz}-\mathrm{COOH})_{2}\right]^{2+}+8$-oxodG generating ECL at $\mathrm{pH} 7.4$

\section{Correlation with Rodent TD50 Genotoxicity Assays ${ }^{3,6,7}$}

Table S2. Correlation of normalized ECL turnover $(R)$ with $\mathrm{TD}_{50}$ data.

\begin{tabular}{|c|c|c|c|c|c|}
\hline & \multicolumn{4}{|c|}{ Turnover rate, $R\left(\mu \mathrm{g}\right.$ of protein $\left.{ }^{-1} \mathrm{~min}^{-1} \mathrm{mM}^{-1}\right)$} & \multirow[t]{2}{*}{ TD $_{50}{ }^{7}$} \\
\hline & HLuM & HLM & HIM & $2 B 6$ & \\
\hline NNK & 148 & 38 & 39 & 59 & 0.0999 \\
\hline $\mathbf{N N N}$ & 110 & 60 & 48 & 92 & 0.0957 \\
\hline
\end{tabular}

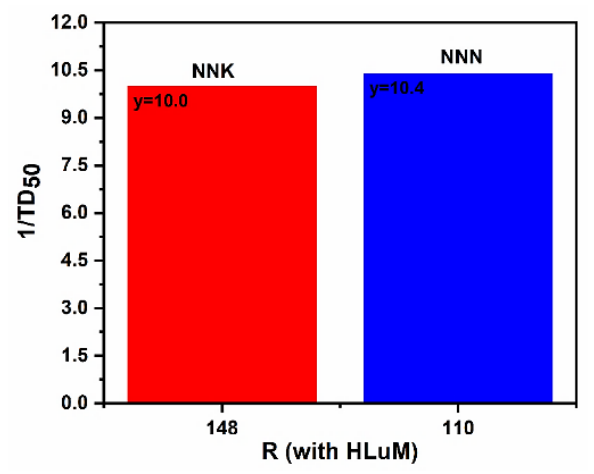

Figure S6: Turnover rate, $\mathrm{R}\left(\mu \mathrm{g}\right.$ of $\left.\operatorname{protein}^{-1} \mathrm{~min}^{-1} \mathrm{mM}^{-1}\right)$ for $\mathrm{NNK}$ and NNN metabolized HLuM compared to rodent lung $1 / \mathrm{TD}_{50}$ for NNK and rodent esophagus $1 / \mathrm{TD}_{50}$ for $\mathrm{NNN}$.

\section{UHPLC-MS for 8-oxodG Analysis ${ }^{3,5}$}

Films of PDDA, DNA, and enzymes were grown on $1 \mu \mathrm{m}$ carboxylate-functionalized magnetic beads (Invitrogen Dynabeads) by the LbL method, with final film composition PDDA/cyt P450 source / HuLM/ PDDA/DNA. After dispersing in $10 \mathrm{mM}$ Tris buffer $(200 \mu \mathrm{L}, \mathrm{pH} 7.0)$ magnetic beads were incubated with $\mathrm{NNK}$ and $\mathrm{NNN}(2 \mathrm{mM})$ with NADPH regeneration system and $5 \mathrm{mM} \mathrm{CuCl}_{2}$ at $37^{\circ} \mathrm{C}$ to produce toxic metabolites and ROS that oxidize DNA. After each incubation, the supernatant was removed, and beads were washed twice using $10 \mathrm{mM}$ Tris buffer. Then, DNA was allowed to hydrolyzed off from the beads enzymatically by incubating it with deoxyribonuclease I (400 unit $\mathrm{mg}^{-1}$ of DNA), 
phosphodiesterase I from snake venom ( 0.2 unit mg $^{-1}$ of DNA), phosphodiesterase II ( 0.01 unit mg $^{-1}$ of DNA), $10 \mu \mathrm{L}$ of $10 \mathrm{mM} \mathrm{MgCl}_{2}$, and phosphatase alkaline (1.2 unit $\mathrm{mg}^{-1}$ of DNA) at $37^{\circ} \mathrm{C}$ for $12 \mathrm{~h}$. The oxidized products were separated out by vacuum filtration using a $3 \mathrm{kDa}$ MW cutoff, 96 well filtration plate and the oxidized bases were analyzed by UHPLC/MS/MS. Control experiments were done in the absence of cyt P450 enzyme source as well as without NNK and NNN in reaction mixtures.

The reaction products were separated using a Thermo Scientific Dionex Ultimate 3000 UHPLC system consists of a reversed phase analytical column (Thermo Scientific, Hypersil GOLD C18, $0.3 \times 150 \mathrm{~mm}$ i.d., $3 \mu \mathrm{m}$ particle size), with gradient elution. $10 \mathrm{mM}$ ammonium acetate buffer, $\mathrm{pH} 4.0$ (solvent $\mathrm{A}$ ), and methanol $+0.1 \%$ formic acid (solvent B) were applied as mobile phase. Gradient of mobile phase was optimized and shown in Table S3. Multiple reaction monitoring (MRM) mode were used to quantitatively measure the amount of 8-oxodG and the method was validated by mixing dG standard with 8-oxodG standard (10 $\mu \mathrm{M}$ each). MRM was done in positive ion mode at $3800 \mathrm{~V}, 300{ }^{\circ} \mathrm{C}, 20 \mathrm{~V}$ collision energy for each mas transitions: $\mathrm{dG}(268 \rightarrow 152)$ and 8-oxodG $(284 \rightarrow 168)$.

\begin{tabular}{|c|c|c|}
\hline Time, $\mathbf{m i n}$ & Flow $\left(\boldsymbol{\mu} \mathbf{\mathbf { ~ m i n } ^ { - 1 }}\right)$ & $\mathbf{\%} \mathbf{B}$ \\
\hline 0 & 6 & 1 \\
\hline 6 & 6 & 1 \\
\hline 11 & 6 & 20 \\
\hline 12.5 & 6 & 30 \\
\hline 14 & 6 & 30 \\
\hline 14.5 & 6 & 1 \\
\hline 20 & 6 & 1 \\
\hline
\end{tabular}

Table S3. Mobile phase gradient for the analysis of 8-oxodG. 


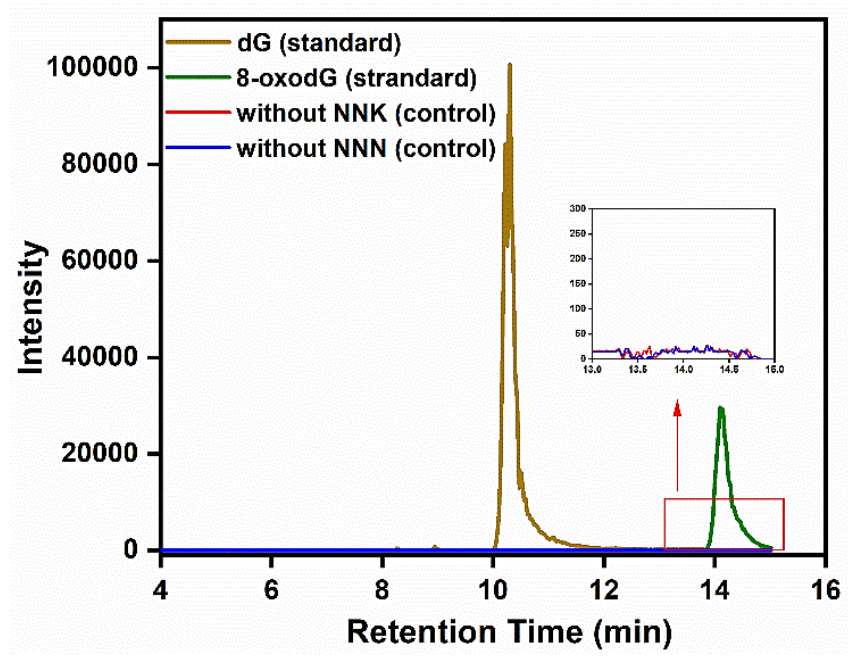

Figure S7. UHPLC-MS results for control experiment in the identification of 8-oxodG. Experiments were done without NNK and NNN in the reaction mixture.

\section{Elucidation of Metabolite Formation and DNA Oxidation by UHPLC-MS/MS ${ }^{3,8}$}

The LC-MS/MS on precursor ions of all metabolites was done using a Thermo Scientific Dionex Ultimate 3000 UHPLC interfaced to a Thermo Scientific TSQ Quantiva triple quadrupole mass spectrometer. $5 \mu \mathrm{L}$ of filtered sample was injected onto a Thermo Scientific, Hypersil GOLD C18, 0.3 $\times 150 \mathrm{~mm}$ i.d., $3 \mu \mathrm{m}$ particle size), with mobile phase $10 \mathrm{mM}$ ammonium acetate buffer, $\mathrm{pH} 4.0$ (solvent A), and methanol $+0.1 \%$ formic acid (solvent B) for gradient elution, at flow rate of $6 \mu \mathrm{L} \mathrm{min}^{-1}$ (Table S4). Product ion scanning was done at $20 \mathrm{~V}$ collision energy. MS1/MS2 was used here and each peak was selected from the MS1, and fragmentation patterns were obtained from the MS2. Then the fragmentation patterns were matched with the proposed structures, by calculating all the $\mathrm{m} / \mathrm{z}$ values

\begin{tabular}{|c|c|c|}
\hline Time & Flow $\left(\boldsymbol{\mu L} \mathbf{~ m i n}^{-1}\right)$ & \% B \\
\hline 0 & 6 & 1 \\
\hline 6 & 6 & 1 \\
\hline 8 & 6 & 90 \\
\hline 13.5 & 6 & 90 \\
\hline 14 & 6 & 1 \\
\hline 20 & 6 & 1 \\
\hline
\end{tabular}

Table S4. Mobile phase gradient for the analysis of reactive metabolites. 


\section{Prediction of Fragmentation Patterns of Metabolites by ACD/Lab MS-Fragmenter Software}

Fragment predicting software; ACD/Lab MS-Fragmenter was used to identify the mass spectral fragmentation pattern, for most of the metabolites of NNK and NNN selected from first mass spectrum in $\mathrm{MS} / \mathrm{MS}$. All the fragmentation patterns are from positive ionization.

\section{Metabolites of NNK:}

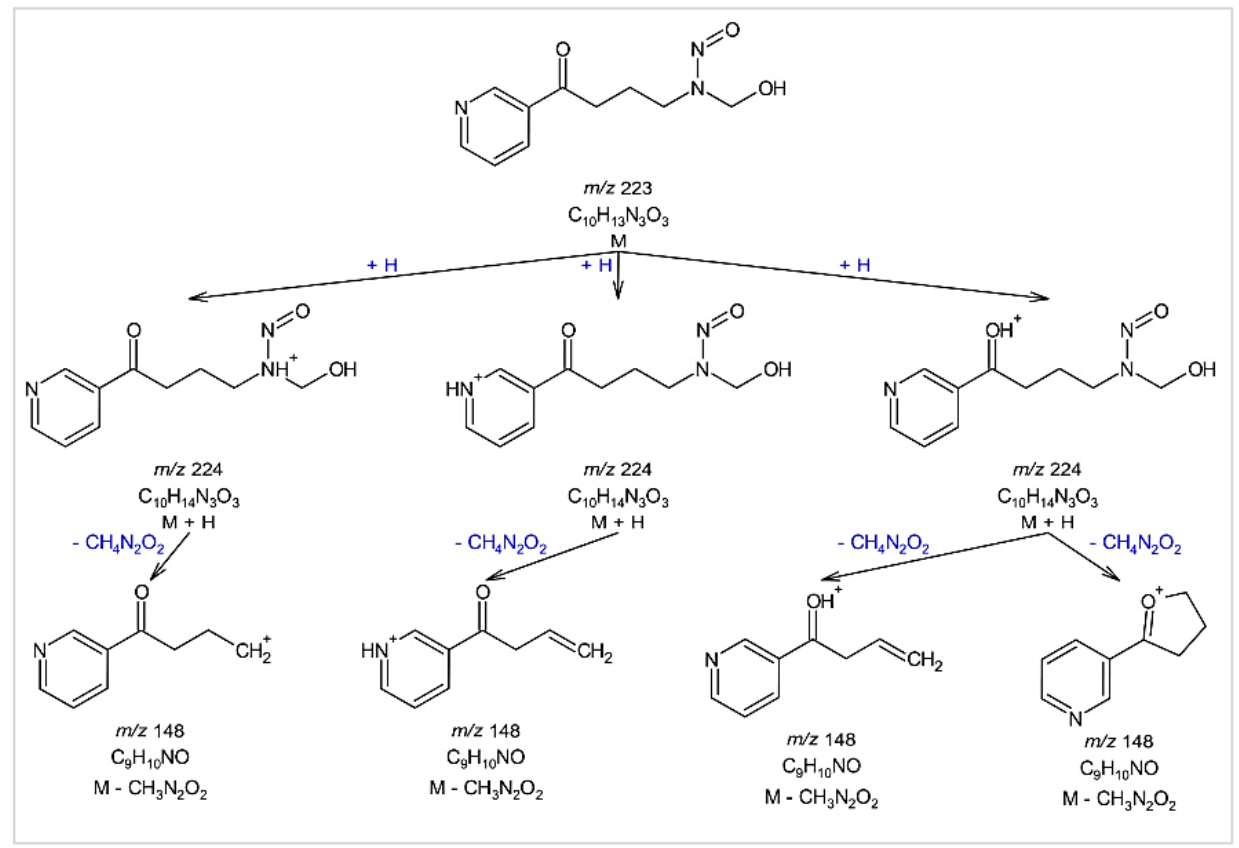

Scheme S3. Predicted fragmentation pattern for NNK metabolite $\alpha$-hydroxynitrosamines $\left((\mathrm{M}+\mathrm{H})^{+}=\right.$ 224.20). 


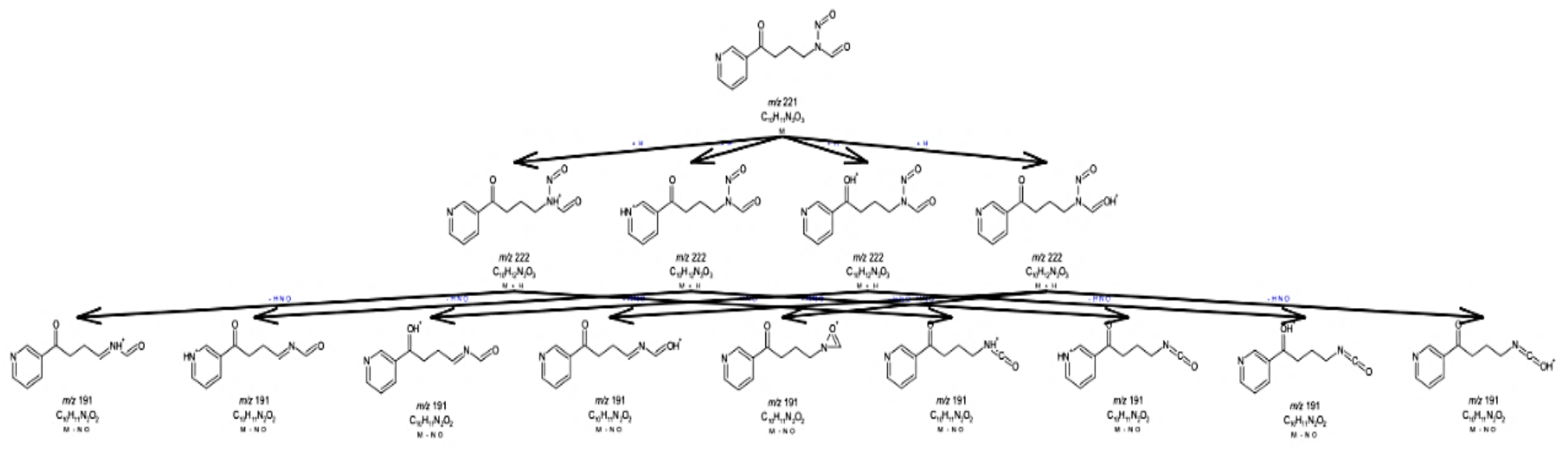

Scheme S4. Predicted fragmentation pattern for NNK metabolite $\alpha$-oxonitrosamines $\left((\mathrm{M}+\mathrm{H})^{+}=\right.$ 222.24).

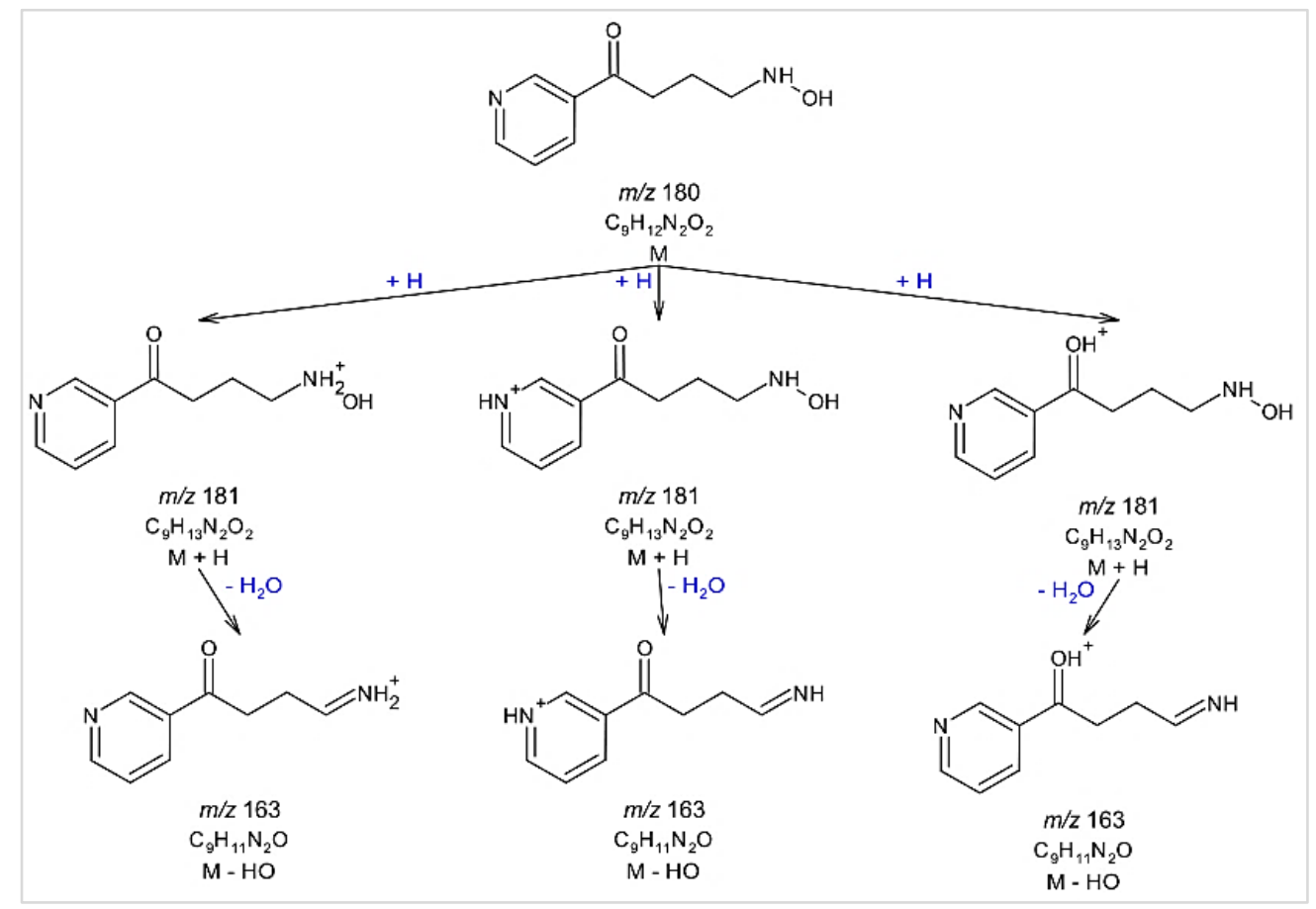

Scheme S5. Predicted fragmentation pattern for NNK metabolite 4- (3-pyridyl)-4-oxobutane-Nhydroxide $\left((\mathrm{M}+\mathrm{H})^{+}=181.19\right)$. 


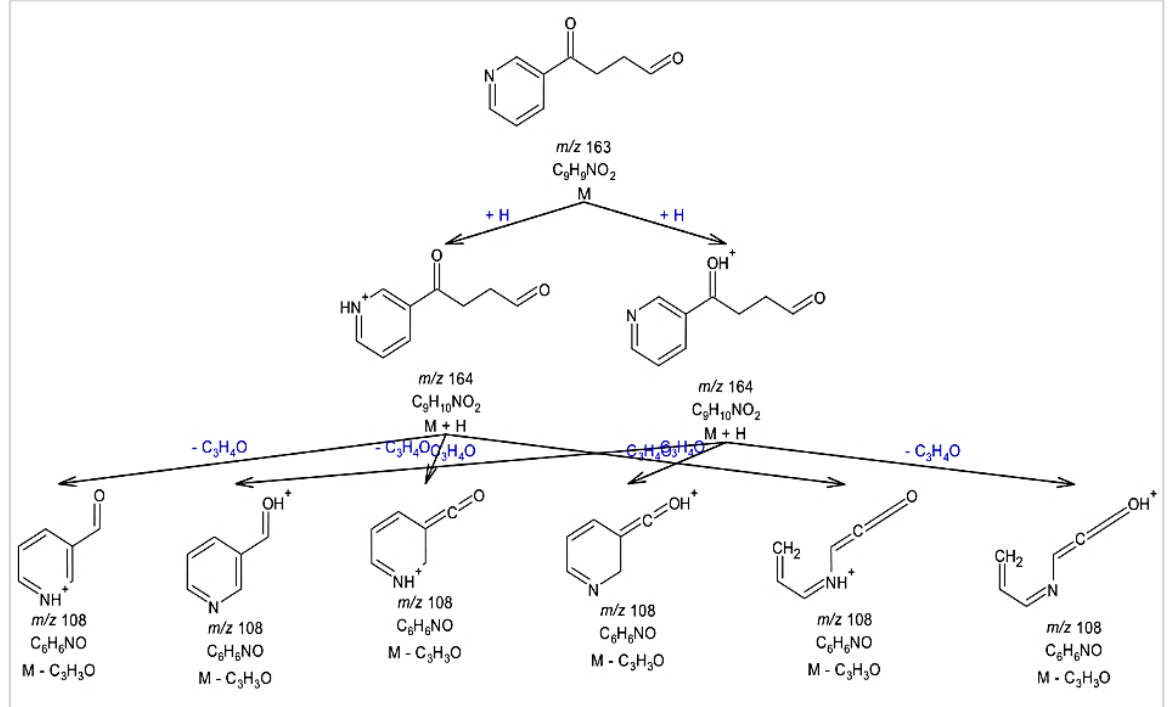

Scheme S6. Predicted fragmentation patterns for NNK metabolite 4-oxo-4-(3pyridyl)butaldehyde $\left((\mathrm{M}+\mathrm{H})^{+}=\right.$ 164.19).

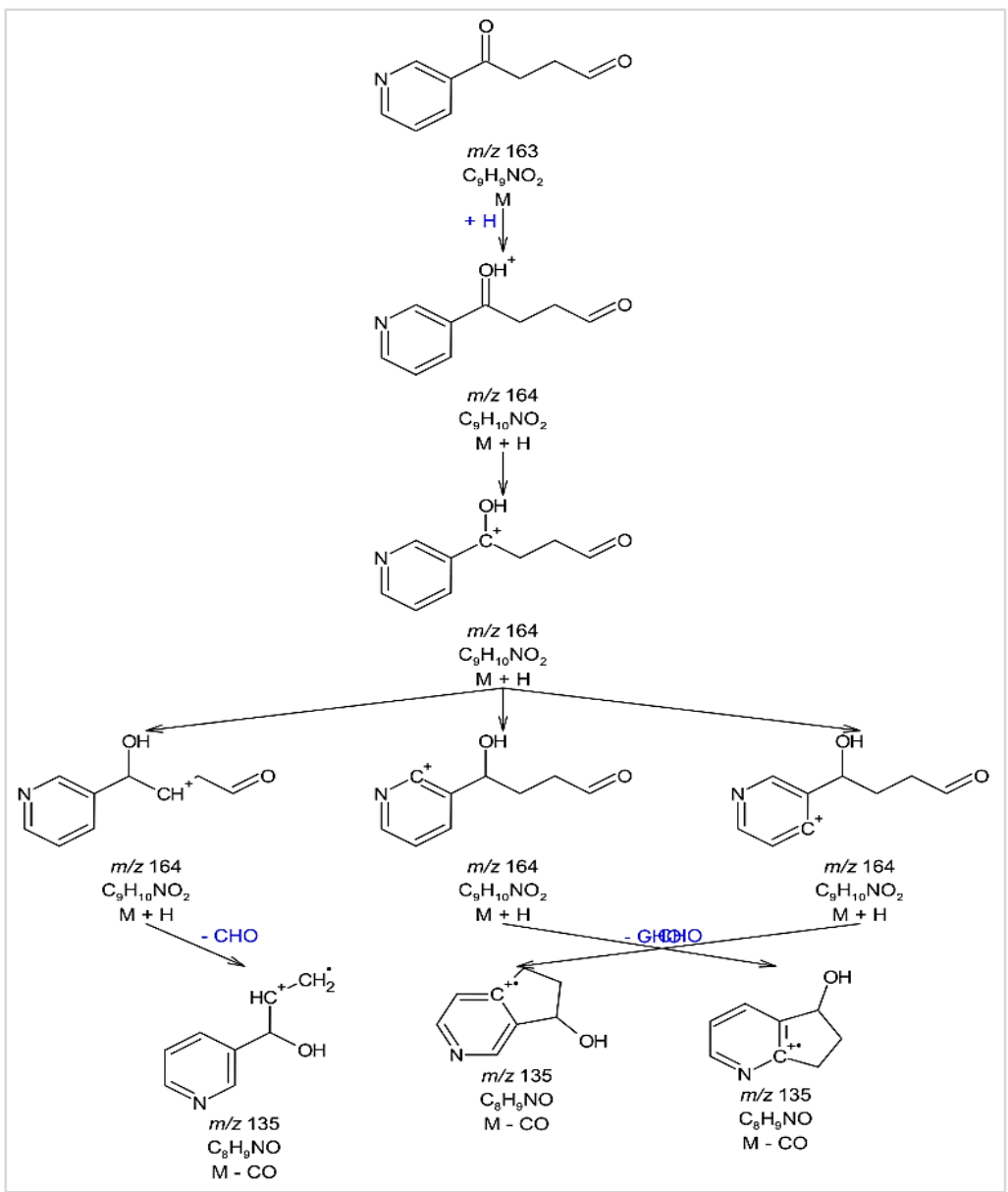




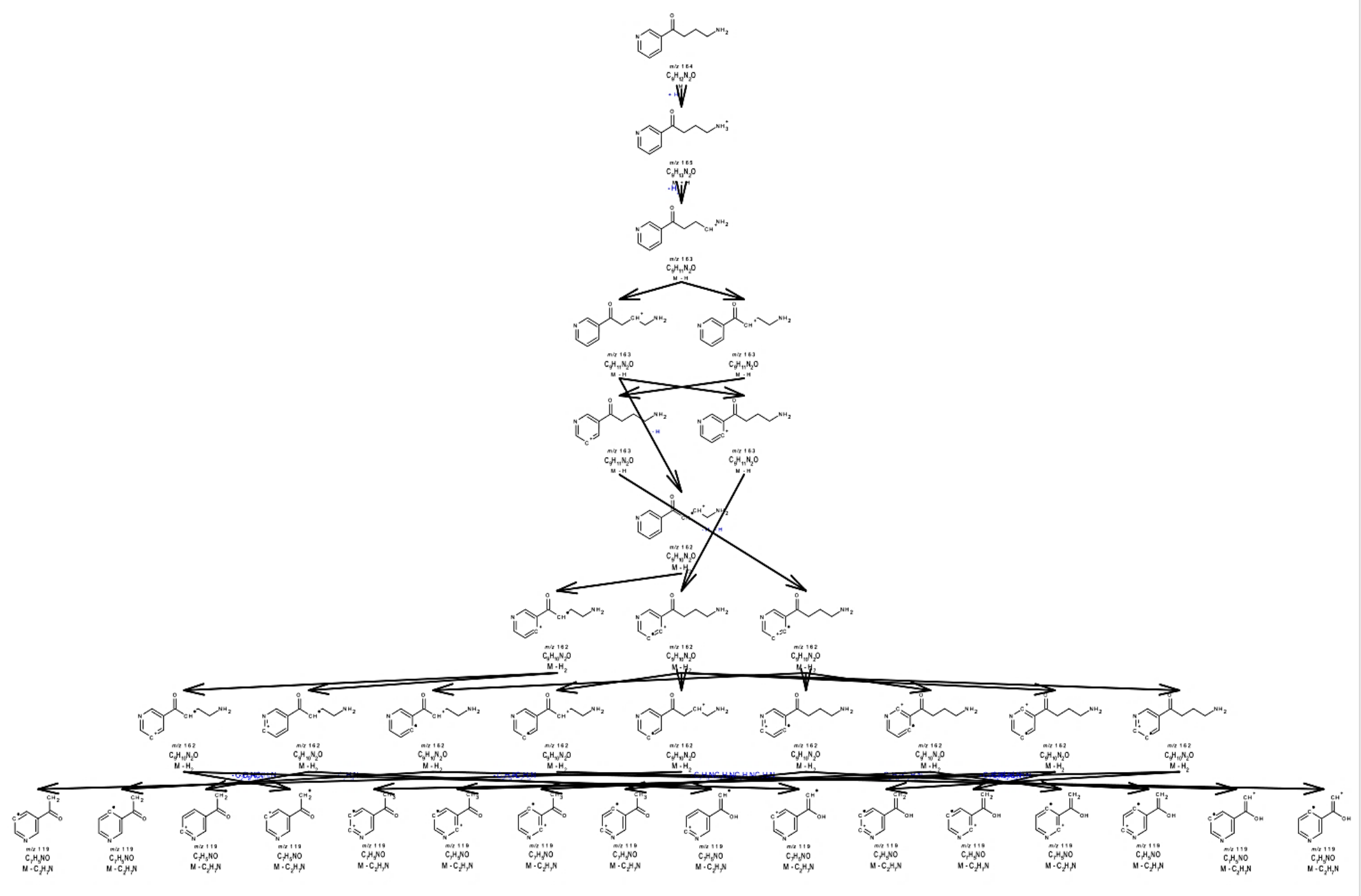

Scheme S7. Predicted fragmentation pattern for NNK metabolite 4-amino-1-(3-pyridyl)-1-butanone $\left((\mathrm{M}+\mathrm{H})^{+}=165.21\right)$. 


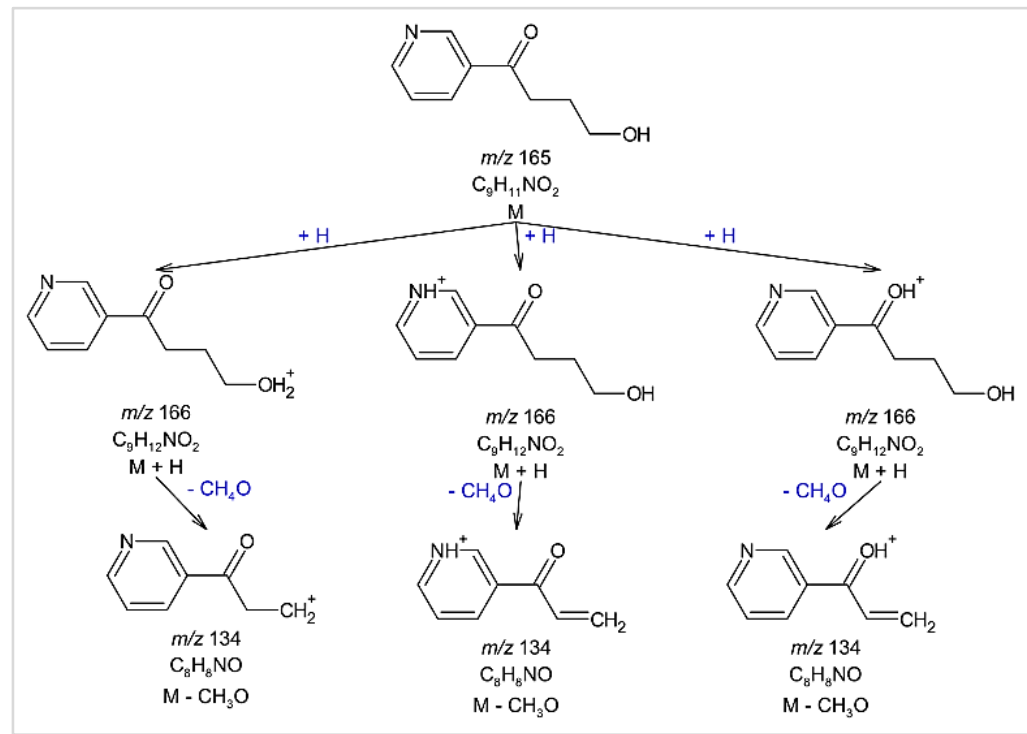

Scheme S10. Predicted fragmentation pattern for NNN metabolite 4-hydroxyl1-(3-pyridyl)-1-butanone (HPB, $\left.\left.(\mathrm{M}+\mathrm{H})^{+}=166.08\right)\right)$.
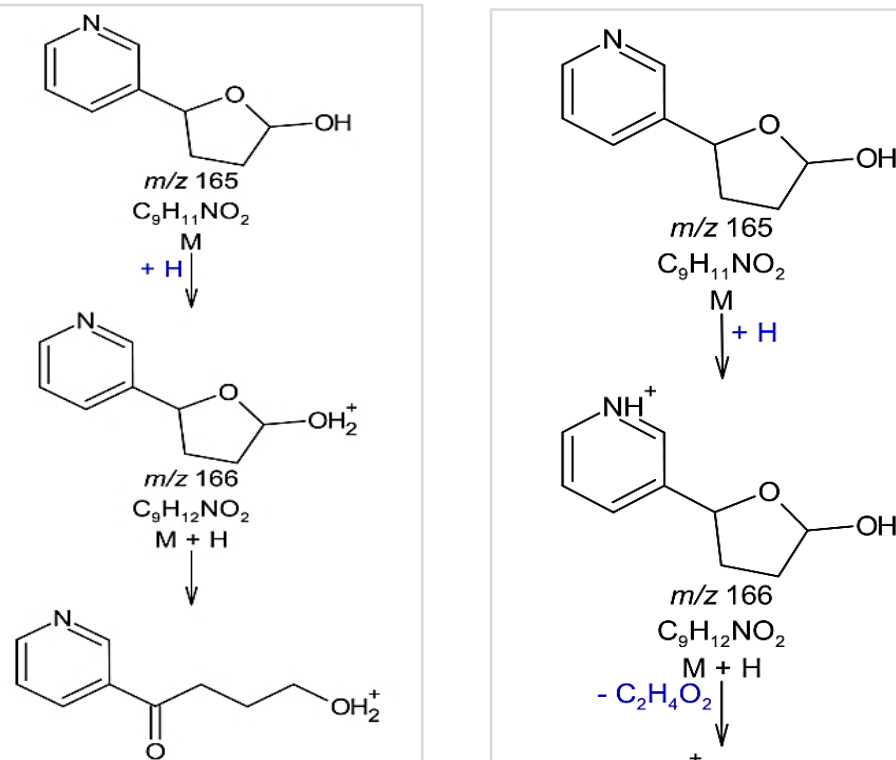

$\mathrm{C}_{9} \mathrm{H}_{11} \mathrm{NO}_{2}$ $\mathrm{M}$

$\downarrow+\mathrm{H}$<smiles>OC1CCC(c2ccc[nH+]c2)O1</smiles>

$m / z 166$

$\mathrm{C}_{9} \mathrm{H}_{12} \mathrm{NO}_{2}$<smiles>CCCO[W]</smiles>

$\mathrm{m} / \mathrm{z} 166$

$\mathrm{C}_{9} \mathrm{H}_{12} \mathrm{NO}_{2}$

$-\mathrm{CH}_{4}^{\mathrm{M}}+\mathrm{H}^{-}$

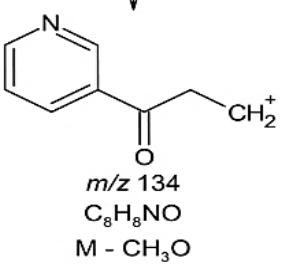

Scheme S11. Predicted fragmentation patterns for NNN metabolite 5-hydroxy2-(3-pyridyl)tetrahydrofuran (lactol, $\left.\left.(\mathrm{M}+\mathrm{H})^{+}=166.06\right)\right)$. 

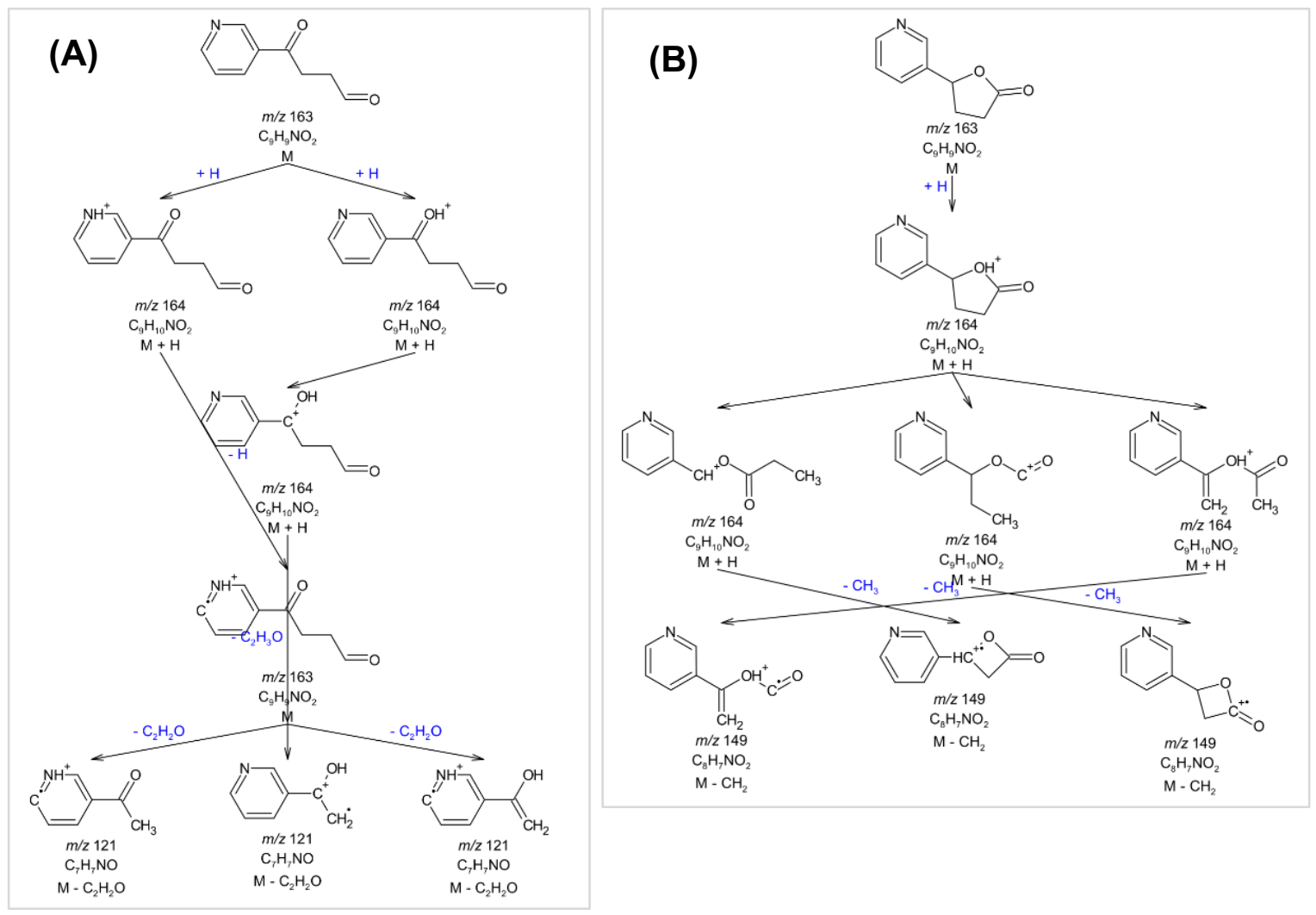

Scheme S12. Predicted fragmentation patterns for NNN metabolites (A) 4-oxo-4-(3-pyridyl)-1-butanal $\left.\left(\mathrm{OPB},(\mathrm{M}+\mathrm{H})^{+}=163.06\right)\right)$ and (B) 5-oxo-2-(3-pyridyl)tetrahydrofuran (lactone, $\left.(\mathrm{M}+\mathrm{H})^{+}=163.06\right)$ ).

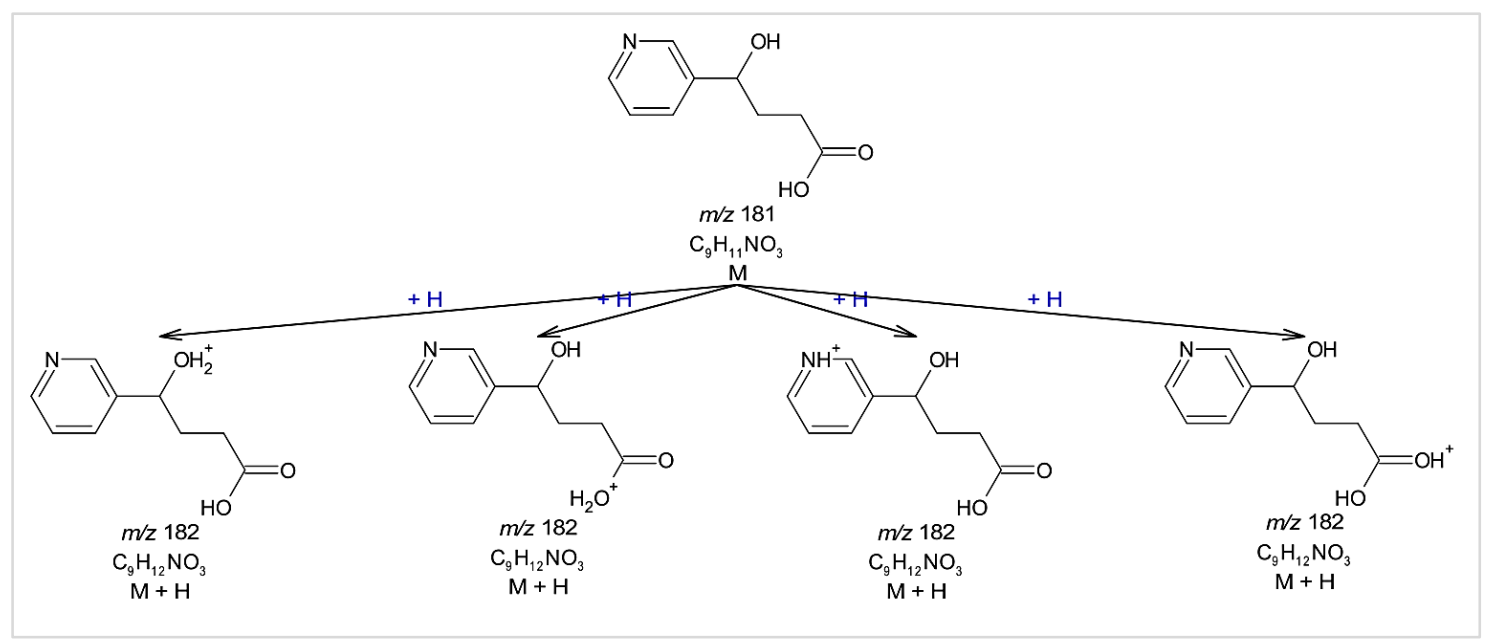

Scheme S13. Predicted fragmentation patterns for NNN metabolite 4-hydroxy-4-(3-pyridyl)butanoic acid $\left.\left(\mathrm{HPBA},(\mathrm{M}+\mathrm{H})^{+}=182.08\right)\right)$. 


\section{ROS Detection}

\section{Reaction Mixture Preparation:}

The enzyme activation for ROS detection was done using MB bioreactors coated with LbL films with and without DNA. In brief, layers of PDDA, DNA, and enzymes were deposited onto $1 \mu \mathrm{m}$ carboxylate functionalized magnetic beads (Invitrogen Dynabeads) by the LbL method, with final film composition PDDA/HLuM/PDDA/DNA (Scheme 3A). After dispersing in $10 \mathrm{mM}$ Tris buffer (200 $\mu \mathrm{L}, \mathrm{pH} 7.0$ ) magnetic beads were incubated with appropriate carcinogenic chemicals (NNK and NNN, $2 \mathrm{mM}$ ), NADPH regeneration system and $5 \mathrm{mM} \mathrm{CuCl}_{2}$ at $37{ }^{\circ} \mathrm{C}$ to produce toxic metabolites and $\mathrm{ROS}$ that oxidize DNA. Fluorescence or absorbance was measured using a BIOTEK Synergy HTX plate reader.

\section{DST Assay for Hydroxyl Radical ('OH) Detection?}

The production of ${ }^{\circ} \mathrm{OH}$ radicals by metabolites in the presence of $\mathrm{Cu}^{2+}$ and NADPH was measured by using disodium terephthalate (DST). Non-fluorescent DST converts into fluorescent 2hydroxyterephthalate, 2-OH-DST $\left(\lambda_{\mathrm{ex}}=300 \mathrm{~nm}, \lambda_{\mathrm{em}}=428 \mathrm{~nm}\right)$ during reaction with ${ }^{\circ} \mathrm{OH}$ radical. DST solution was prepared according to the method described in the literature. After each set of incubations, supernatant was discarded, $200 \mu \mathrm{L}$ DST solution added and fluorescence measured.

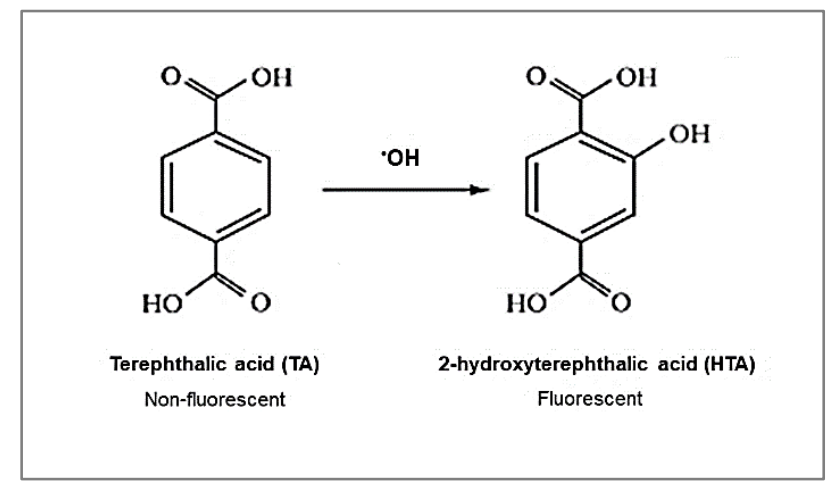

Scheme S14. Mechanism involved in DST assay for the detection of hydroxyl radical. The fluorescent form has excitation wavelength $300 \mathrm{~nm}$ and emission wave length $428 \mathrm{~nm}$.

\section{NBT Assay for Superoxide Radical $\left(\mathrm{O}_{2}{ }^{--}\right)$Detection $^{10}$}

The production of superoxide $\mathrm{O}_{2}{ }^{--}$radicals was investigated using nitroblue tetrazolium (NBT, 2,2'-dip-nitrophenyl-5,5'-diphenyl-(3,3'-dimethoxy)-4,4'-bisphenyleneditetrazolium chloride). The reductive color change from yellowish NBT into purple formazan derivatives in interaction with superoxide radical causes a steady increase of absorbance between 450 and $700 \mathrm{~nm} .200 \mu \mathrm{L}$ of NBT stock solution (10 mg in $3 \mathrm{~mL}$ of water) was added to the previously incubated reaction mixture under light protection. $200 \mu \mathrm{L}$ solutions were taken after every hour and absorption spectra were recorded to quantify superoxide radical in a fluorescence-absorbance plate reader. 


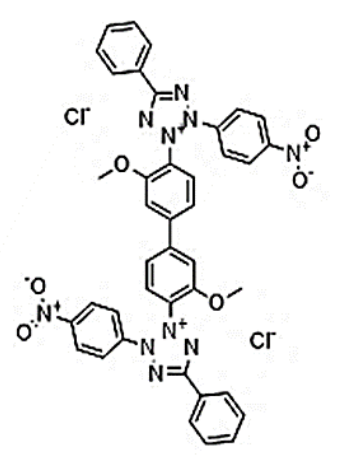

Nitro blue tetrazolium (NBT)

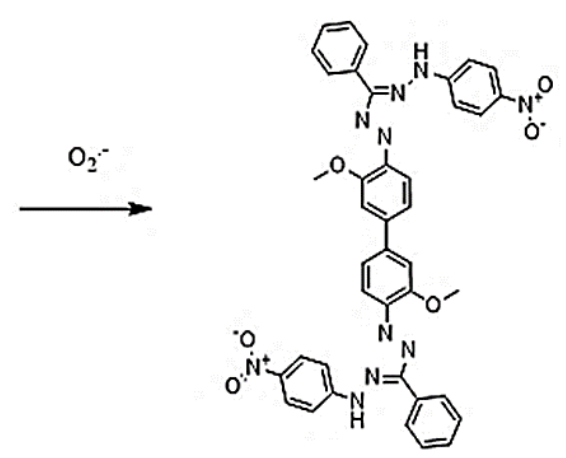

Formazan derivative
Scheme S15. Mechanism involved in NBT assay for the detection of superoxide ion. Formation of formazan derivative in the presence of gives an increase of absorbance between $450 \mathrm{~nm}$ and $700 \mathrm{~nm}$.

\section{SOSG Assay for Singlet Oxygen $\left({ }^{1} \mathrm{O}_{2}\right)$ Detection ${ }^{11}$}

The production of ${ }^{1} \mathrm{O}_{2}$ was monitored using the Singlet Oxygen Sensor Green (SOSG) probe. A yellowish stock solution of SOSG $(25 \mu \mathrm{M})$ was made by dissolving of $100 \mu \mathrm{g}$ of SOSG into $6.6 \mathrm{~mL}$ of methanol. $8 \mu \mathrm{L}$ of SOSG stock solution was introduced into the pre-incubated reaction mixture (final SOSG concentration of $1 \mu \mathrm{M}$ ) and allowed to stay for $1 \mathrm{hr}$. Then, $200 \mu \mathrm{L}$ solution was taken in a microplate and fluorescence of SOSG - endoperoxide (SOSG-EP) $(\lambda \mathrm{ex}=480 \mathrm{~nm}$ and $\lambda \mathrm{em}=525 \mathrm{~nm})$ were measured.

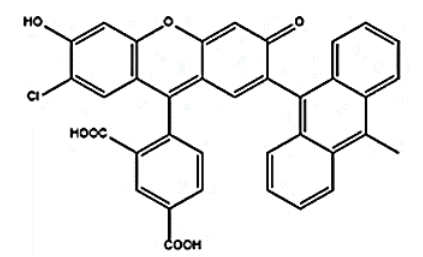

Singlet Oxygen Sensor Green (SOSG) Weakly fluorescent

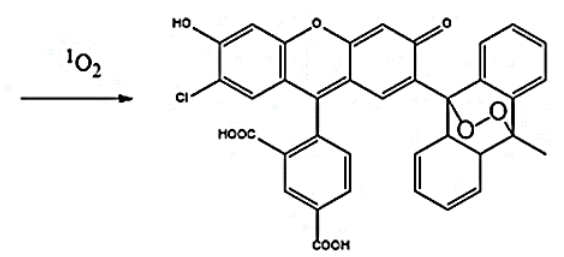

SOSG - EP Highly fluorescent

Scheme S16. Mechanism involved in SOSG assay for the detection of singlet oxygen. SOSG initially exhibits weak blue fluorescence, in the presence of singlet oxygen, it emits a green fluorescence (excitation/emission

maxima $\sim 504 / 525 \mathrm{~nm}$ ) similar to that of fluorescein.

\section{LCV Assay for $\mathrm{H}_{2} \mathrm{O}_{2}$ Detection ${ }^{10}$}

The production of hydrogen peroxide $\left(\mathrm{H}_{2} \mathrm{O}_{2}\right)$ was monitored using leuco crystal violet (LCV) which forms a violet colored cationic species with an absorption peak at $596 \mathrm{~nm}$ in the presence of the enzyme horseradish peroxidase (HRP) and $\mathrm{H}_{2} \mathrm{O}_{2}$. The HRP solution was prepared by dissolving $10 \mathrm{mg}$ of HRP in $10 \mathrm{~mL}$ of DI water. The LCV solution was prepared by dissolving $5 \mathrm{mg}$ of LCV in $10 \mathrm{~mL}$ of $0.5 \%$ $\mathrm{HCl}$ solution. The acetate buffer solution was prepared by adding equal volumes of sodium acetate (2 
M) and acetic acid. The $\mathrm{pH}$ of the buffer was adjusted to 4.5 with glacial acetic acid. $200 \mu \mathrm{L}$ of the reaction mixture were added to $9.8 \mathrm{~mL}$ of distilled water followed by the addition of $1 \mathrm{~mL}$ of the LCV solution, $0.5 \mathrm{~mL}$ of the HRP solution and $5 \mathrm{~mL}$ of the acetate buffer. The mixture was stirred for $1 \mathrm{~h}$ in dark at RT, after which absorbance at $596 \mathrm{~nm}$ was monitored using multi-mode plate reader.

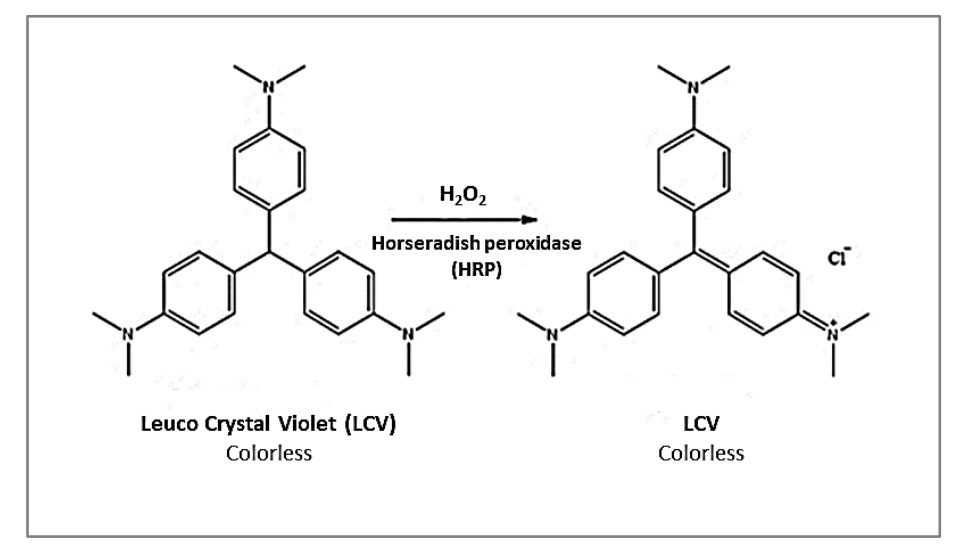

Scheme S17. Mechanism of the assay for hydrogen peroxide detection. Leuco crystal violet (LCV) forms a violet cation absorbing at $596 \mathrm{~nm}$ in the presence of the enzyme horseradish peroxidase (HRP) and $\mathrm{H}_{2} \mathrm{O}_{2}$.

Table S5: Linear regression of graphs in Figure 9 for ROS detection. Values indicate the slopes and intercepts in the equation $\mathrm{y}=\mathrm{mx}+\mathrm{c}$ for each graph and $\mathrm{R}^{2}$ values.

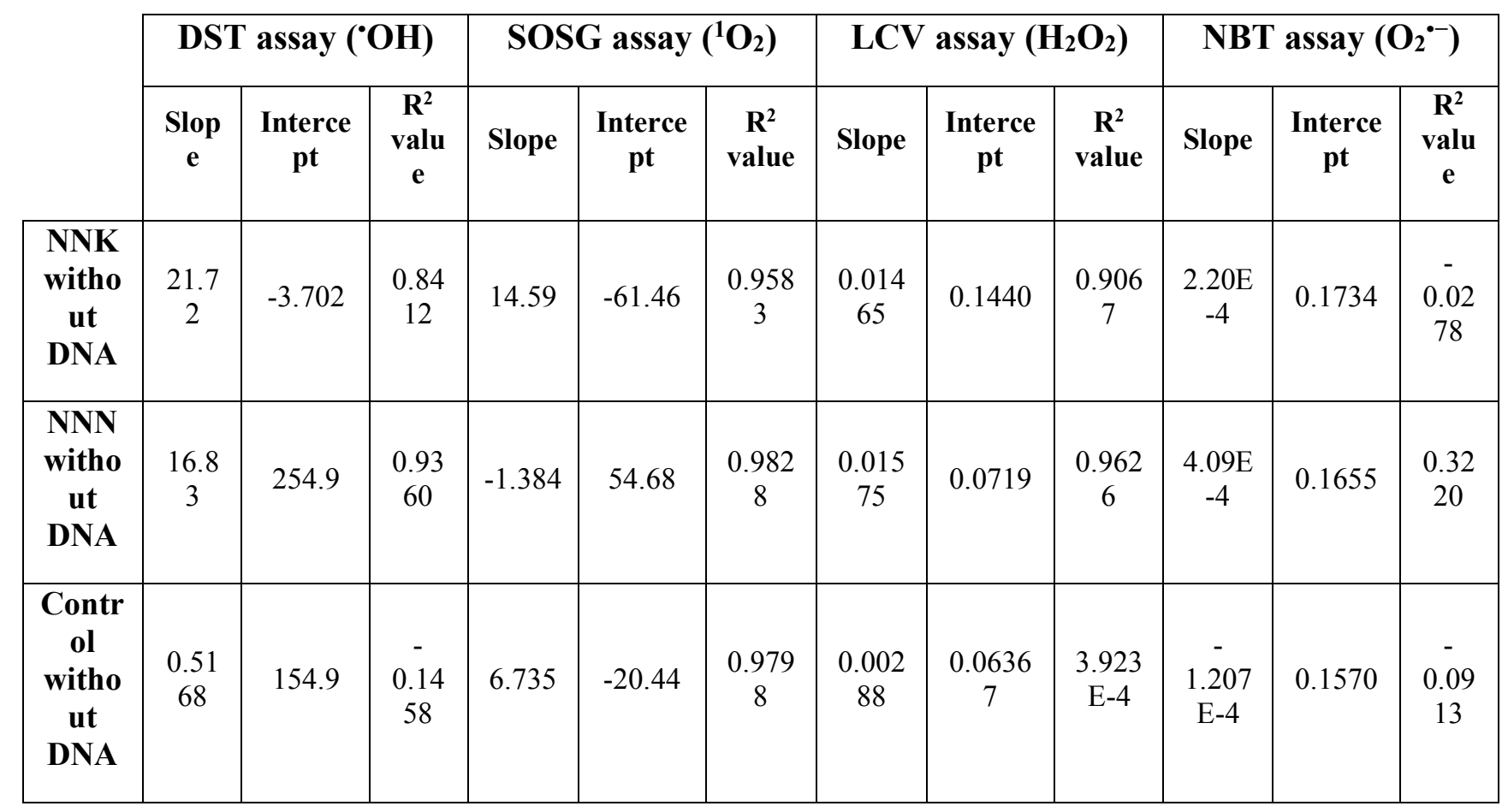




\begin{tabular}{|c|c|c|c|c|c|c|c|c|c|c|c|c|}
\hline $\begin{array}{c}\text { NNK } \\
\text { with } \\
\text { DNA }\end{array}$ & $\begin{array}{c}0.42 \\
38\end{array}$ & 217.4 & $\begin{array}{c}0.10 \\
58\end{array}$ & $\begin{array}{c}0.789 \\
9\end{array}$ & 39.70 & $\begin{array}{c}0.651 \\
0\end{array}$ & $\begin{array}{c}5.971 \\
\mathrm{E}-5\end{array}$ & 0.1802 & -0.250 & $\begin{array}{c}2.303 \\
\mathrm{E}-5\end{array}$ & 0.1776 & $\begin{array}{c}0.24 \\
85\end{array}$ \\
\hline $\begin{array}{c}\text { NNN } \\
\text { with } \\
\text { DNA }\end{array}$ & $\begin{array}{c}1.28 \\
1\end{array}$ & $\begin{array}{c}240.59 \\
4\end{array}$ & $\begin{array}{c}0.79 \\
58\end{array}$ & $\begin{array}{c}0.098 \\
93\end{array}$ & 13.10 & $\begin{array}{c}0.025 \\
85\end{array}$ & $\begin{array}{c}1.390 \\
\mathrm{E}-4\end{array}$ & 0.1962 & $\begin{array}{c}0.248 \\
5\end{array}$ & $\begin{array}{c}5.215 \\
\mathrm{E}-4\end{array}$ & 0.1635 & $\begin{array}{c}0.30 \\
18\end{array}$ \\
\hline $\begin{array}{c}\text { Contr } \\
\text { ol } \\
\text { with }\end{array}$ & $\begin{array}{c}1.96 \\
\text { DNA }\end{array}$ & $\begin{array}{c}143.47 \\
2\end{array}$ & $\begin{array}{c}0.77 \\
89\end{array}$ & $\begin{array}{c}0.023 \\
88\end{array}$ & 10.09 & -0.198 & $\begin{array}{c}0.001 \\
92\end{array}$ & 0.1029 & $\begin{array}{c}0.155 \\
8\end{array}$ & $\begin{array}{c}8.486 \\
\mathrm{E}-5\end{array}$ & 0.1554 & $\begin{array}{c}0.18 \\
58\end{array}$ \\
\hline
\end{tabular}

\section{References}

(1) Alemán, E. A., Shreiner, C. D., Rajesh, C. S., Smith, T., Garrison, S. A., and Modarelli, D. A. (2009)

Photoinduced Electron-Transfer within Osmium(II) and Ruthenium(II) Bis-Terpyridine Donor Acceptor Dyads. Dalt. Trans. 33, 6562-6577.

(2) Gkika, K. S., Byrne, A., and Keyes, T. E. (2019) Mitochondrial Targeted Osmium Polypyridyl Probe Shows Concentration Dependent Uptake, Localisation and Mechanism of Cell Death. Dalt. Trans. 48 (47), 17461-17471.

(3) Bist, I., Bhakta, S., Jiang, D., Keyes, T. E., Martin, A., Forster, R. J., and Rusling, J. F. (2017) Evaluating Metabolite-Related DNA Oxidation and Adduct Damage from Aryl Amines Using a Microfluidic ECL Array. Anal. Chem. 89 (22), 12441-12449.

(4) Bist, I., Song, B., Mosa, I. M., Keyes, T. E., Martin, A., Forster, R. J., and Rusling, J. F. (2016) Electrochemiluminescent Array to Detect Oxidative Damage in Ds-DNA Using [Os(Bpy)2(Phen-BenzCOOH)]2+/Nafion/Graphene Films. ACS Sensors 1 (3), 272-278.

(5) Wasalathanthri, D. P., Malla, S., Faria, R. C., and Rusling, J. F. (2012) Electrochemical Activation of the Natural Catalytic Cycle of Cytochrome P450s in Human Liver Microsomes. Electroanalysis 24 (11), 2049-2052. 
(6) Pan, S., Zhao, L., Schenkman, J. B., and Rusling, J. F. (2011) Evaluation of Electrochemiluminescent Metabolic Toxicity Screening Arrays Using a Multiple Compound Set. Anal. Chem. 83 (7), 2754-2760.

(7) Padma, P. R., Amonkar, A. J., and Bhide, S. V. (1989) Mutagenic and Cytogenetic Studies of N'Nitrosonornicotine and 4-(Methylnitrosamino)-1-(3-Pyridyl)-1-Butanone. Cancer Lett. 46 (3), 173-180.

(8) Song, B., Shen, M., Jiang, D., Malla, S., Mosa, I. M., Choudhary, D., and Rusling, J. F. (2016) Microfluidic Array for Simultaneous Detection of DNA Oxidation and DNA-Adduct Damage. Analyst $141(20), 5722-5729$.

(9) Moussa, H., Merlin, C., Dezanet, C., Balan, L., Medjahdi, G., Ben-Attia, M., and Schneider, R. (2016) Trace Amounts of $\mathrm{Cu}^{2+}$ Ions Influence ROS Production and Cytotoxicity of ZnO Quantum Dots. J. Hazard. Mater. 304, 532-542.

(10) Nosaka, Y., and Nosaka, A. Y. (2017) Generation and Detection of Reactive Oxygen Species in Photocatalysis. Chem. Rev. 117 (17), 11302-11336.

(11) Donat, F., Corbel, S., Alem, H., Pontvianne, S., Balan, L., Medjahdi, G., and Schneider, R. (2017) ZnO Nanoparticles Sensitized by CuInZn x S 2+x Quantum Dots as Highly Efficient Solar Light Driven Photocatalysts. Beilstein J. Nanotechnol. 8, 1080-1093. 